\title{
SCIENCE AND PRACTICE IN RESEARCH PROCESS
}

\author{
Henryk DŹWIGOŁ \\ Silesian University of Technology, Faculty of Organization and Management; henryk.dzwigol@poczta.fm, \\ ORCID: 0000-0002-2005-0078
}

Purpose: The aim of the article is to compare the results of research on the use of research methods and techniques in solving management problems and in verifying which of the two acceptable approaches in the research process dominates among practitioners and theoreticians of management sciences.

Design/methodology/approach: The survey was conducted by means of a questionnaire. The research was addressed to management science theoreticians and management practitioners being the target group covering: 272 foreign universities; 21,024 foreign researchers; 93 domestic universities; 2,307 domestic researchers; 52 foreign companies, 183 domestic companies. As a result of the research effort, 401 representatives of management science theoreticians and 118 practitioners were examined.

Findings: The carried-out research has made it possible to identify methods, procedures, techniques and approaches that are most relevant to research processes in management sciences. Furthermore, both scientists and practitioners of management sciences use the same research methods.

Research limitations/implications: It should be stated that management science and the methods used in it should support business practice and, to some extent, provide guidance to managers and directors. Management should be treated as a normative science, the aim of which is to formulate the principles of effective and efficient functioning of enterprises.

Practical implications: The conclusions resulting from the carried-out research explicitly indicate that both scientists and practitioners of management sciences use the same research methods, i.e.: analysis of documentation, questionnaire, observation and interview. Research results obtained during the research process in the field of management sciences should be applied in practice.

Social implications: Owing to the involvement of scientists and practitioners in research, it can be concluded that, while defining a research problem, it is difficult to choose a single method which allows for a full and thorough diagnosis of the problem under investigation. It is therefore necessary, in the research process, to use a variety of methods which will provide a comprehensive response to the posed problem.

Originality/value: The research carried out has made it possible to identify methods, procedures, techniques and approaches that are most relevant to the research processes in management sciences. They were carried out in two stages. The commitment of both theoreticians and practitioners to the research process resulted in a broader interpretation of management sciences and allowed the author to diagnose the studied issues more fully and thoroughly.

Keywords: research process, management sciences, research methods and techniques. 


\section{Introduction}

The most important feature of the strategic management is reliance on facts, and on research and analyses conducted in a reliable way. Managerial intuition, or luck in business can only apply in areas where it is impossible or too expensive to obtain adequate knowledge (Barney, and Hesterly, 2010). Nowadays, strategic management has been understood as a process of creating the future through continuous development and implementation of strategies (Ansoff et al., 2018). The continuity of strategic thinking, analysis of reality, drawing conclusions and transforming them into new strategic decisions is now becoming a fundamental feature of effective strategic management. (Hitt, and Duane Ireland, 2017).

In the methodology of social sciences, two approaches can be distinguished, i.e. the first is nomothetic and the second one is idiographic (Lyon et al., 2017; Korulczyk et al., 2019). The nomothetic approach is based on the quest for general laws and rules of the natural world (Holloway, and Galvin, 2016). Typical research procedures within this approach include: experiments (Kirschen, 2018), inspections and correlation, whereas appropriate methods cover: interviews, surveys, observations, experimentations and testing (Hair et al., 2019). The idiographic approach is based on explaining phenomena in such a way that it should lead to the identification of external events that could shape these phenomena in a qualitative way (Tsoukas, 1989; Carrier, 2012). As to this approach, a case study is regarded as an appropriate research procedure (Buck, and Shahrim, 2005; Dul, and Hak, 2016), whereas methods used in this area may include: documentation analysis, interviews, observations, or projection tests (Carminati, 2018). The distinction of the idiographic approach was the result of focusing on the search for characteristic features that distinguish a given phenomenon from others (Thomae, 1999).

In accordance with the common classification of sciences, economic sciences are considered to have a utilitarian or theoretical-nomological function (Myrdal, 1987). Due to the fact that the management-related sciences are part of economic sciences, this role also applies to them. Nomothetics will occur when a general law is established on the basis of a case-bycase analysis. Idiographic methodology, on the other hand, can be identified when the aim of research will be to learn, explain the essence and characteristics and to understand one particular event (Salvatore, and Valsiner, 2010).

The problem of choosing the tools to understand and explain a given phenomenon, especially in social sciences, depends on the paradigm of science. Nonetheless quantitative research is generally considered to be 'better' and to provide more reliable knowledge than qualitative research. In many cases, however, due to the characteristics of the problem, research must be of a qualitative nature (Dźwigoł, 2018). 
Research methods and techniques have been, over the past years, subject to thorough changes and developments (Ferran-Ferrer et al., 2017; Almalki, 2016; Tonidandel et al., 2016). In management sciences, one can observe a trend of rejecting traditional thinking in favour of combinative thinking. (Hair, 2019; Dźwigoł, 2019). Research methods and techniques in management sciences are aimed at finding out about rules and principles that govern organisations, and at changing the said organisations for better (Quinlan et al., 2019).

A method can be defined as a conscious and resolute way in which a researcher acts or behaves in order to achieve a defined goal (Dźwigoł, 2019).

A technique, on the other hand, can be defined as an instrument, tool used to solve appearing problems (Dźwigoł, 2019).

However, from the practical point of view it is not easy to distinguish between a method and a technique. Regardless of a researcher's decision about applying a research method or a research technique, the researcher is always obliged to implement a determined research process (Bryman, 2006; Vaivio et al., 2010). A research process consists of numerous elements; the said elements should be meticulously planned on the basis of continuous choices. The said choices are to be made in consideration of reliability and credibility of research findings (Cooke, 2003).

\section{Research method}

The conclusions of the conducted literature analysis on research methods and techniques in management sciences demonstrate the need for a comparative analysis of a group of theoreticians and practitioners in the context of the most commonly used research methods and approaches in the research process.

With reference to the foregoing, the aim of the article is to verify:

- whether both theoreticians and practitioners most often use the same research methods in order to solve the management research problems they identified during their work,

- which of the two approaches, allowed in the research process, dominates in the given group,

- whether statistically significant differences can be observed in answers to the same questions about research methods and techniques, asked to a group of theoreticians and practitioners and built on the Likert scale.

In order to find answers to the posed research questions, the research study involved an anonymous survey questionnaire carried out from October 2016 to April 2018.

The questionnaire consisted of three parts. The first part contained questions about the importance of approaches, processes, methods and techniques in a research process within the scope of management sciences (5 questions). The second part consisted of questions related to 
the problem of the improvement of a research process (33 questions). The third part contained demographics (3 questions) (Dźwigoł, 2018).

The research was addressed to management science theoreticians and management practitioners being the target group covering: 272 foreign universities; 21,024 foreign researchers; 93 domestic universities; 2,307 domestic researchers; 52 foreign companies, 183 domestic companies.

As a result of the research effort, 401 representatives of management science theoreticians and 118 practitioners were examined.

\section{Research results}

The quantitative research was carried out by means of 2 questionnaires, which were directed to, respectively, theoreticians and practitioners from the field of management sciences. The size of a research sample, necessary to determine a representative character of the research among theoreticians, was established on the basis of the following assumptions:

- the $p$ fraction ratio was set to 50\% (This approach shall be admissible, should the population volume be unknown),

- the size of an error related to the fraction ratio was set to $5 \%$,

- statistical significance $\alpha=0.05$.

On the basis of the above-mentioned assumptions, the requested sample size formula will be simplified, and look as follows (Kukuła, 2007, pp. 138-141):

$$
n_{p}=\frac{u_{\alpha}^{2} * p(1-p)}{b_{p}^{2}}=\frac{u_{\alpha}^{2}}{4 b_{p}^{2}}=\frac{1,96^{2}}{4 * 0,05^{2}}=384,16
$$

where:

$n_{p}$ - advocated sample size,

$\mathrm{u}_{\alpha}-$ amount of cumulative normal distribution derived from statistical table,

$\mathrm{p}$ - fraction ratio,

$\mathrm{b}-$ size of the fraction ratio error.

Since 401 representatives of management science theorists were surveyed, it was determined that the number shall be seen as representative. The representative sample should be used to draw conclusions that may be transferred to the population identified previously while investigating the research problem raised in this paper. Efforts have also been made to ensure that the questionnaires are filled in by as many expert respondents as possible on the subject matter undertaken. 
The survey for theoreticians consisted of 41 questions, 33 of which were structured on a 5point Likert scale, while the descriptive answers were converted into numbers 1-5 for further analysis. Such a step was necessary to apply statistical methods such as: reliability analysis, factor analysis, correlation analysis.

\section{Which of these test methods should be used in research processes within management science}

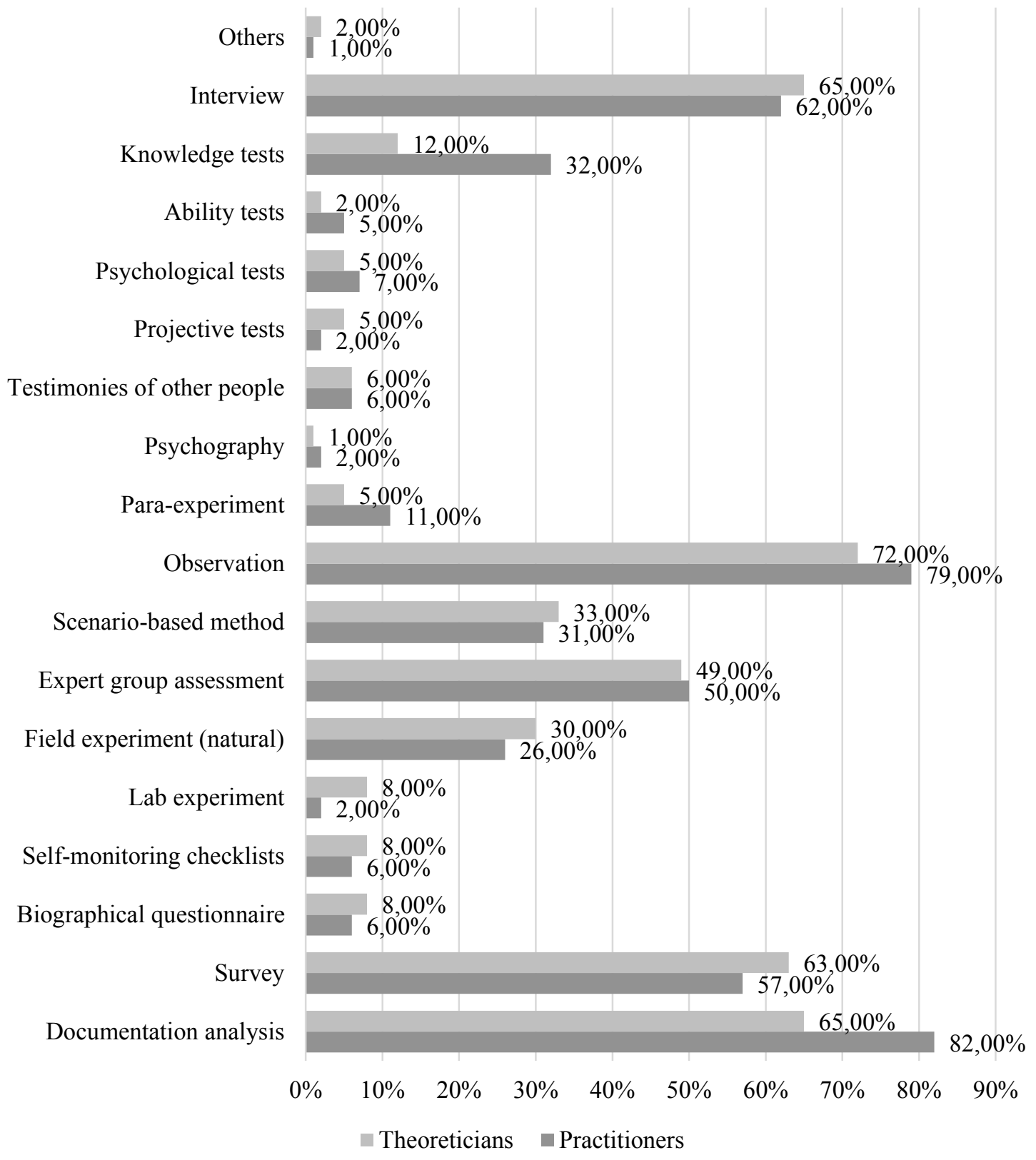

Figure 1. Method-related share in the examined groups. Author's own study.

By analysing the obtained results, it can be concluded that there are research methods that stand out in both groups, and they include: documentation analysis, questionnaire, observation and interview. As a criterion of affiliation to the outstanding methods, it has been assumed at the author's discretion that the share of a given method in both groups should exceed 0.5 . 
This indicator can be interpreted as follows: the aforementioned methods form a set which practitioners and theoreticians most often make use of.

Moreover, observation is the most frequently indicated research method by management theorists. The research, which is based on observation, usually provides only a superficial and indicative overview of the data collected in its course. Observation can be considered as one of the most universal and comprehensive techniques of collecting information. For this reason, and because of its complexity, there is a tendency to refer to it as a research method. This trend cannot be regarded as appropriate, since observation takes central place among cognitive ways, as it involves a lot of ancillary techniques. It is therefore a comprehensive way of conducting research which, at the same time, also remains the most primaeval because of its history, as well as its essence, when considered individually.

However, the most frequently indicated method by practitioners is the analysis of documentation, which, in their opinion, most often illustrates the essence of the problem under investigation.

\section{Which approach: nomothetic or idiographic prevails within management science and management practice}

Since there are two types of approaches in management sciences: a nomothetic one and an idiographic one, it was necessary to examine which one prevails. The question included only one possible answer, which resulted in a total of one.

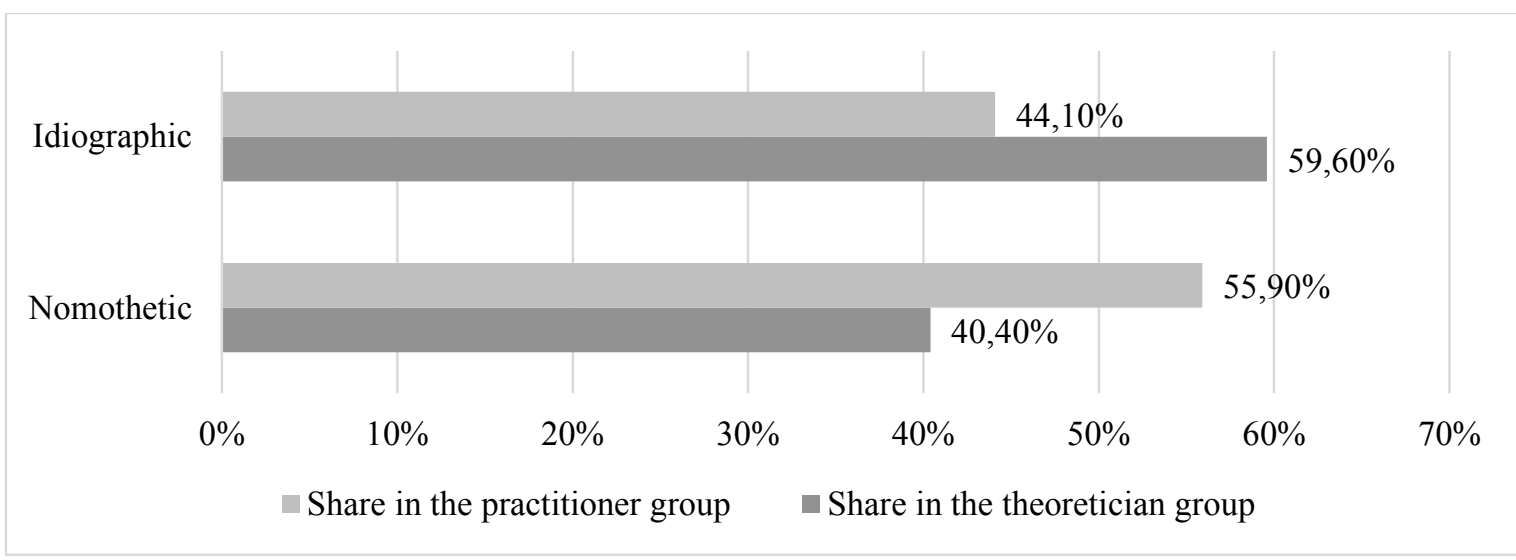

Figure 2. Approach-related share in the examined groups. Author's own study.

On the basis of the obtained research results it was found out that the idiographic approach prevails among theoreticians. It can also be stated that the theoreticians choose the idiographic approach more often, because they are required to indicate unique aspects of the studied phenomenon. On the other hand, in the group of practitioners, the nomothetic approach prevails. It can also be stated that practitioners are more likely to choose the nomothetic approach because indicating the universal dimensions, characteristics or regular relationships between the various aspects of the phenomenon has a significant impact on reducing the possibility of business failure. 
For the sake of management sciences that have been developed for functioning of economic entities, steps should be taken to select a set of research problems that are more relevant to practitioners. Such a set task requires finding a way to implement the tool, model, recommendation and procedure developed during the research process in the surveyed industries.

\section{Strategic nature of cooperation between science and practice in a modern enterprise}

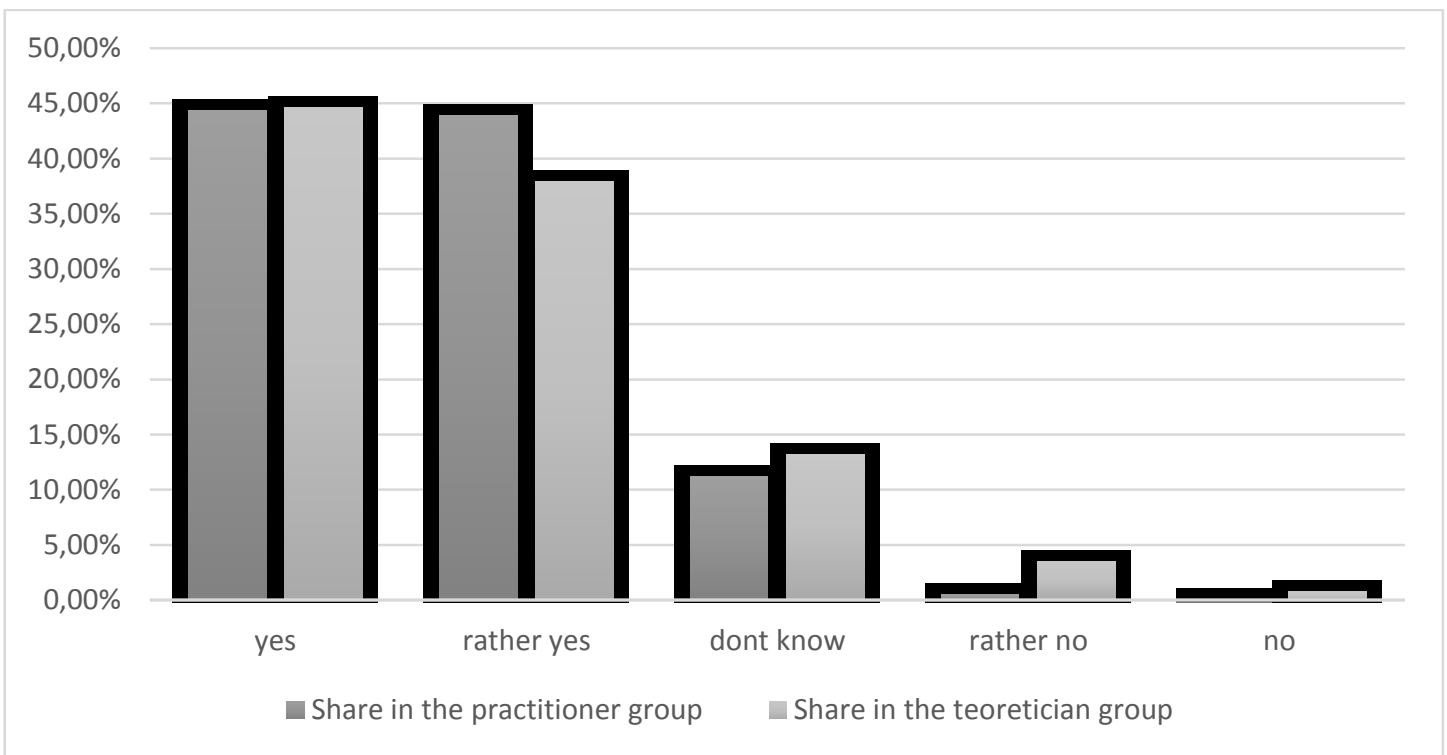

Figure 3. Cooperation between science and practice should be of strategic character in the process of managing a modern enterprise. Author's own study.

According to the author, the strategic nature of cooperation between science and practice in a modern enterprise is a necessary prerequisite for the development of both spheres of management sciences. Since the question was built on the basis of the 5-stage Likert scale, the Mann-Whitney U-Test was used to compare the answers, which examines the differences between the medians in groups, taking into account their size.

\section{Table 1.}

The Mann-Whitney U Test (with consideration given to its continuity) for the variable related to the strategic nature of cooperation between science and practice in a modern enterprise

\begin{tabular}{|c|c|c|c|c|}
\hline \multirow{2}{*}{ Variable } & \multicolumn{3}{|c|}{$\begin{array}{r}\text { The Mann-Whitney U Test for a presented variable } \\
\text { Marked results are relevant, with p } \mathbf{p . 0 5}\end{array}$} \\
\cline { 2 - 5 } & $\begin{array}{c}\text { The P-value } \\
\text { in the U-Test }\end{array}$ & Test statistics & $\begin{array}{c}\text { Valid N - } \\
\text { theoreticians }\end{array}$ & $\begin{array}{c}\text { Valid } \mathbf{N}- \\
\text { practitioners }\end{array}$ \\
\hline $\begin{array}{c}\text { Strategic nature of cooperation } \\
\text { between science and practice in } \\
\text { a modern enterprise }\end{array}$ & 0.466727 & -0.727816 & 401 & 196 \\
\hline
\end{tabular}

Source: Author's own work.

On the basis of the above table, it can be concluded that there are no statistically significant differences between the researched groups. In practice, it comes down to stating that both practitioners and theoreticians see a clear need for the strategic nature of cooperation between science and practice in a modern enterprise. Despite the existence of a solid theoretical basis 
for creating new management methods, there is still a lack of description of real experiences and their implementation, and thus better integration of science and practice. The large variety of new ventures in management systems and the examples of good practice sought by senior managers are often not complementary. Although there are no significant differences in methodological approaches between practice and science, it is becoming necessary to tighten the integration of the two worlds. Dilemmas are inherent in any change being introduced and are used as a kind of leverage mechanism in the process of introducing methodological changes that can integrate both sides. The difficulty of integration rests on the answer to the question: how to do it and implement it into the real life of organisations and their management? It is necessary to develop a model, procedure, tool or approach to the research process
itself

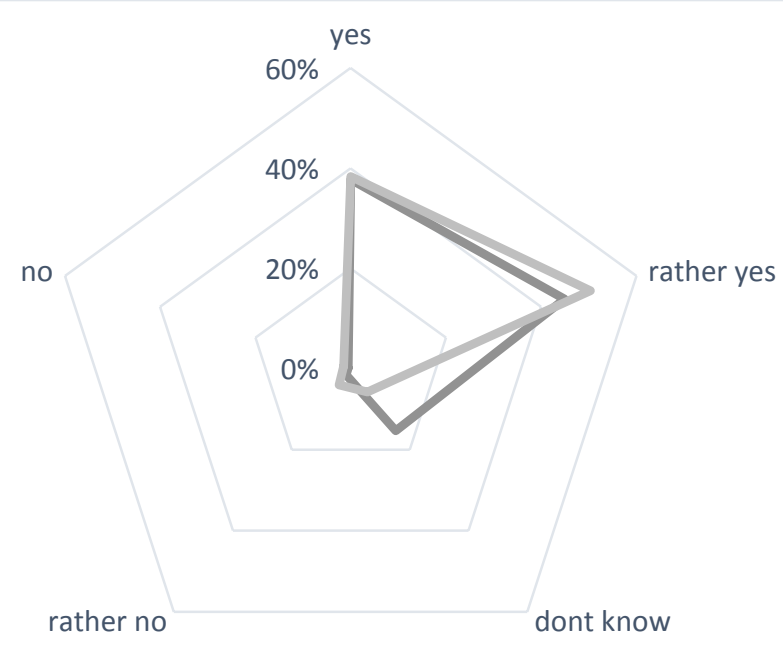

Share in the practitioner group $\longrightarrow$ Share in the teoretician group

Figure 4. It is necessary to develop a model, procedure, tool or approach to the research process itself. Author's own study.

The answer to the question whether it is necessary to develop a model, procedure, tool or approach to the research process itself has also been subject to the above-mentioned static test.

\section{Table 2.}

The Mann-Whitney U-Test (with consideration given to continuity) for a variable related to the need of devising a model

\begin{tabular}{|c|c|c|c|c|}
\hline \multirow{2}{*}{ Variable } & \multicolumn{4}{|c|}{$\begin{array}{c}\text { The Mann-Whitney U-Test for a presented variable } \\
\text { Marked results are relevant, with p }<\mathbf{0 . 0 5}\end{array}$} \\
\cline { 2 - 5 } & With corrections & $\mathbf{p}$ & Valid N - theoreticians & Valid N - practitioners \\
\hline A need for a model & -0.790014 & 0.429520 & 401 & 196 \\
\hline
\end{tabular}

Source: Author's own work. 
On the basis of the above table, it can be concluded that there are no statistically significant differences between the researched groups. In practice, it comes down to stating that both practitioners and theoreticians see a clear need to develop a model, procedure, tool or approach to the research process itself. Both practitioners and scientists see a clear need to design a methodology for the research process in management science to guide it.

The change and transformation of enterprises are bringing about an increase in the level of complexity of organisations, which requires a fresh look at the emergence of new trends in management sciences. The co-operation of theoreticians and practitioners in developing new methods of management opens up new opportunities to integrate their potential.

Researchers should comprehensively illustrate the entire complexity of the problems to be solved, and practitioners should play the role of a reviewer-implementer, improving the interpretation of necessary changes and problems for their realistic conditions, especially in a dynamic environment.

\section{Summary and research findings}

The aim of the article was to compare the results of research on the use of research methods and techniques to solve management problems, to verify which of the two acceptable approaches in the research process dominate among practitioners and theoreticians of management sciences.

The research carried out allowed to identify the methods, procedures, techniques and approaches that are most relevant to the research process in management sciences. They were carried out in two stages. The involvement of theoreticians and practitioners in the research process resulted in a broader perspective on the management sciences and allowed the author to diagnose the studied issues more fully and thoroughly.

The conclusions of the conducted research clearly indicate that both scientists and practitioners of management science have used the same research methods, i.e.: analysis of documentation, questionnaire, observation and interview.

Thanks to the involvement of scientists and practitioners in research, it can be concluded that when defining a research problem, it is difficult to choose one method that gives the possibility of a full and thorough diagnosis of the problem under consideration. Therefore, it is necessary to use various methods in the research process, which will provide a comprehensive response to the problem. Thanks to this broadly conducted research it was possible not only to determine the most important methods and techniques used by management theorists, but also to check whether they are also used in practice. 
Analysing the above solutions, it should be stated that management science and the related methods used should support business practice and, to some extent, provide instructions to directors and managers. Management should be treated as a normative science, the aim of which is to formulate rules of effective and efficient functioning of enterprises. Research results obtained during the research process in the field of management sciences should be applied in practice.

\section{References}

1. Almalki, S. (2016). Integrating Quantitative and Qualitative Data in Mixed Methods Research-Challenges and Benefits. Journal of Education and Learning, 5(3), doi:10.5539/jel.v5n3p288.

2. Ansoff, H.I., Kipley, D., Lewis, A.O., Helm-Stevens, R., \& Ansoff, R. (2018). Implanting strategic management. Springer.

3. Barney, J.B., \& Hesterly, W.S. (2010). Strategic management and competitive advantage: Concepts and cases. Upper Saddle River, NJ: Prentice Hall, 4-25.

4. Bryman, A. (2006). Integrating quantitative and qualitative research: How is it done? Qualitative Research, 6(1), 3-37, https://doi.org/10.1177/1468794106058877.

5. Buck, T., and Shahrim, A. (2005). The Translation of Corporate Governance Changes Across National Cultures: The Case of Germany. Journal of International Business Studies, 36(1), 42-64.

6. Carminati, L. (2018). Generalizability in Qualitative Research: A Tale of Two Traditions.

7. Carrier, J.G. (Ed.) (2012). A handbook of economic anthropology. Edward Elgar Publishing.

8. Dul, J. and Hak, T. (2016). Case Study Methodology in Business Research. New York: Routledge.

9. Dźwigoł, H. (2018). Współczesne procesy badawcze w naukach o zarzadzaniu. Uwarunkowania metodyczne i metodologiczne. PWN: Warszawa.

10. Dźwigoł, H., Dźwigoł-Barosz, M., Zhyvko, Z., Miśkiewicz, R., Pushak, H. (2019). Evaluation of the energy security as a component of national security of the country. Journal of Security and Sustainability Issues, 8(3), 307-317. http://doi.org/10.9770/ jssi.2019.8.3(2).

11. Ferran-Ferrer, N., Guallar, J., Abadal, E., and Server, A. (2017). Research methods and techniques in Spanish library and information science journals (2012-2014). Information Research, 22(1).

12. Hair, J.F., Page, M., and Brunsveld, N. (2019). Essentials of Business Research Methods. Routledge: New York, https://doi.org/10.4324/9780429203374. 
13. Hitt, M., \& Duane Ireland, R. (2017). The intersection of entrepreneurship and strategic management research. The Blackwell handbook of entrepreneurship, 45-63.

14. Holloway, I., \& Galvin, K. (2016). Qualitative research in nursing and healthcare. John Wiley \& Sons.

15. Kirschen, D.S., \& Strbac, G. (2018). Fundamentals of power system economics. John Wiley $\&$ Sons.

16. Korulczyk, T., Biela, A., \& Blampied, N. (2019). Being more idiographic in the nomothetic world. Polish Psychological Bulletin, 50(2), 207-216.

17. Lyon, A.R., Connors, E., Jensen-Doss, A., Landes, S.J., Lewis, C.C., McLeod, B.D., \& Weiner, B.J. (2017). Intentional research design in implementation science: implications for the use of nomothetic and idiographic assessment. Translational behavioral medicine, 7(3), 567-580.

18. Myrdal, G. (1987). Utilitarianism and modern economics. In: Arrow and the Foundations of the Theory of Economic Policy (pp. 273-278). Palgrave Macmillan: London.

19. Quinlan, Ch., Babin, B., Carr, J., and Griffin, M. (2019). Business Research Methods. South Western Cengage.

20. Salvatore, S., \& Valsiner, J. (2010). Between the general and the unique: Overcoming the nomothetic versus idiographic opposition. Theory \& Psychology, 20(6), 817-833.

21. Thomae, H. (1999), The Nomothetic-Idiographic Issue: Some Roots and Recent Trends. International Journal of Group Tensions, 28, 187-215, https://oi.org/10.1023/ A:1021891506378.

22. Tonidandel, S., King, E.B., and Cortina, J. (2016). Big Data Methods: Leveraging Modern Data Analytic Techniques to Build Organizational Science. Organizational Research Methods, 21(3), 525-547, DOI: 10.1177/1094428116677299.

23. Tsoukas, H. (1989). The validity of idiographic research explanations. Academy of management review, 14(4), 551-561.

24. Vaivio, J., \& Sirén, A. (2010) Insights into method triangulation and "paradigms" in interpretive management accounting research. Management Accounting Research, 21(2), 130-141, https://doi.org/10.1016/j.mar.2010.03.001. 